\title{
Use of Athletics and Debate in Developing Competencies Among Learners:Perception of Teachers
}

\author{
Atuta Omweri Eric ${ }^{1} \quad$ Beatrice N. Manyasi ${ }^{{ }^{*}} \quad$ Joash Migosi $^{2}$ \\ 1. Maasai Mara University, School of Education, P.0. Box 861- 20500, Narok, Kenya \\ 2. University of Nairobi, School of Education
}

\begin{abstract}
The study investigated Teachers Perception of the Use of Athletics and Debate in Developing Competencies among learners in secondary schools in Kenya. The Objectives of the study were: To determine teachers' perception of participation in athletics in developing competencies among learners; and to examine teachers' perception of participation in debates in developing competencies among learners. A descriptive research design was used in describing teacher's perception of the use of debate and athletics in developing competencies among learners. The target population comprised of 80 teachers who were in charge of co-curricular activities. Census sampling technique was used hence all the 80 teachers formed the study sample. Questionnaires were used to collect data. To ensure validity, the instruments were reviewed by an expert supervisor. The researcher conducted a pilot study of the questionnaires to test their reliability. Data was analyzed and interpreted according to the objectives. It was presented using frequencies and percentages. The findings revealed that Use of Athletics and Debate in developing competencies among learners in secondary schools facilitated in building confidence, promoting citizenship, communication and collaboration, critical thinking, creativity, imagination and social skills. The researcher recommends that: learners should be allowed to choose the kind of co-curricular activity they want to participate in, schools should create time for co-curricular activities during formal school hours, the Government of Kenya should come up with a policy to ensure co-curricular activities are made compulsory in all secondary schools. The overall outcome of the study will contribute to existing knowledge and provide baseline data for further studies on the use of co-curricular activities in developing competencies among learners.
\end{abstract}

Keywords: co-curricular activities, Athletics, Debate, Competencies, learners

DOI: $10.7176 / \mathrm{JEP} / 10-35-08$

Publication date: December $31^{\text {st }} 2019$

\section{Introduction}

The greatest concern for all educational institution is the learners' competency, development and progress. Schools everywhere in the world are the basis for future competent leaders and citizens. For successful learning and future application of knowledge, schools are expected to offer combinations of attitudes and skills. It is therefore important that schools offer academic curriculum, being the basic plan, together with other co-curricular activities, to act as the influencer of basic knowledge. Basically, co-curricular activities and academic work should be looked at holistically and equally (Miller 2007). It is important that educational experiences should not only include formal knowledge that helps learners develop intellectually and mentally but also impart a lot of other experiences for their social, physical and spiritual development (Winston et al 2008).

Globally, other countries had realized how important co-curricular activities are to learners and this has helped them to enhance the review of their education system to make sure that competencies are identified early. The different routine activities involving learners' participation in schools have direct effect on their competencies, right from secondary schools level. In the United States of America (USA), co- curriculum activities have been associated with improved education level, higher interpersonal competences, better attention level and higher aspirations (Mahoney, Cairos \& Farwer, 2003). Also, in the United States of America, more than half of the school going children is involved in various co-curricular activities (Gardner, Roth and Brook-Gunn at el, Mahoney and Eccles, 2006). Eccles (2003), in his study found out that learners in the united states of America spends almost an hour of their walking hours in leisure activities, that is, participation in co-curricular activities like athletics, music, drama and debate. Another good example is Brazil where the country has produced well known footballers who play their trade across elite European clubs. This in turn earns their country foreign exchange in form of money repatriated back to their country.

Participation in co-curricular activities has to increase personal and social maturity and critical thinking (Bauer \& Liang, 2003), high motivations, and beneficial service to bridge school activities with those done outside academic setting showed that there is a variety of CCAs being carried out in schools and their implementation is influenced by several factors. These factors are; resource allocation, pre- planning of the activities, training of students and patrons of CCA, monitoring and evaluation of the CCA, the learners' perception regarding the value of CCA also implementation to other learners and the rest of the school. It is a confirmed fact by classical and modern educationists, that education is not memorization of knowledge but rather a balance of all-round development. Interestingly therefore, it will be logical to think that co-curricular activities are the integral part of 
educational system. Kumar et. al (2004) comments that co-curricular activities hold a high place in the educational field of an all-round development of learners. He further adds that, for spiritual, social, and physical developments, co-curricular activities are prerequisite. Co-curricular activities help learners not to fall in the realm of the ordinary educational curriculum (Bashir, 2012).

In Kenya the policy initiatives were developed to assist in improving and accessing education were introduced under the Economic Recovery Strategy for wealth and Employment (ERS, 2003-2007). The key policy reforms included the development of Sessional Paper No.1 of 2005 which resulted to adoption of a Sector Wide Approach to Planning (SWAP) to the provision of education. The approach involved a wide range of stakeholders to support the system of education from primary to secondary level of education. Because of the SWAP process, Kenya Education Sector Support Program (KESSP) was developed by the government of Kenya and other development partners. The program was aimed at improving access, equity, retention and completion of education by the learners both at the primary and secondary level of education (MOEST: 2005). It is notable in Kenya that the secondary education has changed in the past few decades. This is in bid for the government to increase the number of graduates in order for the citizens to have the ever changing skills needed for the current knowledge-based economy. And so, a number of self-funded community colleges have been set up to provide a wide range of degree programs which have actually proven to play a key role in imparting the needed skills. The 8-4-4 system of education was itself competitive in nature, that is, it focused only on academic performance of the learners unlike the new system of education 2-6-3-3-3 which focus on competency based curriculum. The new system of education entails both curriculum and co-curricular activities. The learners who participate in co-curricular activities are able to make new friends and develop skills and interests outside the regular school curriculum (Mwisukha, Njororai and Onywera, 2003). Although educational system in Kenya recognizes both curricular activities and co-curricular activities, researchers such as Ongonga et al. (2010), observes most schools in Kenya are totally in line with the curriculum and totally out of phase with participation in co-curricular activities (Castelli et al.2007). Co-curricular activities have been downgraded by the schooling systems under the belief that they are a waste of time necessary to improve academic performance. Educational system should aim at holistic curriculum that equips learners allround for the reality of life. Most of the learners who come from Gucha Sub County are not able to effectively exhibit competencies required after their graduation. During the education day which was held in one of the schools and attended by the Gucha sub-county education officer and some politicians, they both made a public outcry that most learners after completing their secondary education, were not able to communicate properly, exercise their democratic rights as required, did not portray appropriate leadership skills and lacked appropriate social skills. The curriculum emphasized academic achievement of learners in terms of grades. Some parents also did not want their children to participate in co-curricular activities because they believed that these activities consumed academic time unnecessarily. This led to increased idleness among learners, that is, instead of learners directing their energies to participation in co-curricular activities, they become idle hence indiscipline cases went up. The unspent energy due to idleness from the learners is one of the factors which have led to increased learners' unrest in public secondary schools, decreased talents, low levels of critical thinking, poor communication and poor social skills. Few studies have been done to establish the use of co-curricular activities in developing competencies among learners in public secondary schools in kisii county, Kenya, but none has focused on the teachers' perception of the use of co-curricular activities in developing competencies among learners in public secondary schools. The study focused on the influence of co-curricular activities on academic performance among learners in public secondary schools in Kenya. This study therefore sought to investigate the teachers' perception of the use of cocurricular activities in developing competencies among learners in public secondary schools in kisii county, Kenya.

\section{Purpose of the Study}

The main Purpose of the study was to investigate the teachers' perception on the use of co-curricular activities in developing competencies among learners in public secondary schools in Gucha sub county, Kisii County, Kenya. The following were the objectives of the study:

a) To determine teachers' perception of participation in athletics in developing competencies among learners.

b) To examine teachers' perception of participation in debates in developing competencies among learners.

\section{LITERATURE REVIEW}

\subsection{Co-curricular Activities in Education}

According to the National Education Policy (2009) of the Government of Pakistan, the system of education should empower learners in promoting their hidden talents and skills and facilitate them to play their effective roles in the development of the society. Education should infuse in them the spirit of patriotism and build their character, quality of tolerance, social justice and democracy so that they can easily know their history and culture. Cocurricular activities are significant in developing competencies among the learners. The research carried out by 
department of education in the United States of America discovered that learners who contributed actively in cocurricular events had higher chances of improving their life aspects and general competency in comparison to the learners who did not participate in any co-curricular events (Stephens and Schaben, 2002). Similarly, another study revealed that irrespective of the point that learners belong to various places, their past achievements, home participation, participation in positive events, they aid positively in improving their examination score or GPA (Simon, 2001). Educationists discovered that curricular activities possess some impact on behavior together with developing competencies among learners. Initially, co-curricular events were viewed as for recreational purposes only hence they were not encouraged by both the teachers and the parents (Marsh and Kleitman, 2002). However, it is recently when school administration and educationists from various educational institutions began noticing that co-curricular activities have positive effect on learners (Marsh and Kleitman 2002).

The co-curricular events have been divided to formal and non-formal events. Formal events involve learners' participation in debates, dramas, and sports competition. However, informal events involve watching television and listening to music. It has been proposed that formal and informal events contain varying impacts in developing competencies among learners (Guest and Schneider, 2003). Some researchers discovered that spending more time in the informal events makes an incompetent learner as well as establishing poor working habits whereas spending more time on formal event such as debate, sports and drama events, makes one to become more competent later in life (Marsh and Kleitman, 2002). The implementation of good values in every activity conducted in school can create a generation that is capable of making reasonable decisions as well as responsible towards their actions and attitudes. Human capital must be trained, educated, and developed within the organization system in order to improve organizational productivity through the expertise of the workforce. In addition, education is the best contributing factor to the differences in people's income under certain situations, therefore, co-curricular activities are considered to be very effective in fostering a balance between mental, spiritual, physical and social development of the learners (International Conference on Education and Regional Development 2016, Indonesia 778).

\subsection{Development of Competencies}

Participation in any co-curricular activities is important in developing various competencies necessary for the learners in their future life. In the United States of America, more than half of the young people who attend schools are involved in various co-curricular activities (Gardner, Roth and Brooks-Gunn et al. Mahoney, Harris, and Eccles, 2005such as: athletics, drama, music among others. Eccles (2003) found out that learners in the United States of America spend almost an hour in leisure activities. Most researchers have raised serious concerns on how time meant for leisure is being spent and even wondering why there were high levels of disinterest, underachievement, disengagement and increased amount of time learners spend not supervised by the adults. In a research conducted by Gardner et al. (2008), theory and research on positive youth development, emphasizes the transition of human development and suggest that cultivating positive, supportive relationships with people and social institutions encouraged health development. Considering this perspective, participation in co-curricular activities like athletics, music, drama and debate leads to development of competencies which are desired in future life of the learners. Therefore, teachers and learners ought to understand the benefits of participating in various cocurricular activities and also be able to consider how to balance academics and co-curricular activities in order to have a positive impact on the learners. According to Gardner, Roth and Brooks-Gunn (2008), participation in organized co-curricular activities at the level of secondary schools are associated positively with competencies like leadership skills, social skills and talent development among the learners.

Morrissey (2005), found out that there was an established link between learners' co-curricular activities and educational attainment. He also noted that participation in these activities led to reduction in delinquency. Therefore, participation in co-curricular activities is critical for the development of competencies that the learner will carry into adulthood. The study by Gardner, Roth and Brooks-Gunn (2008), also indicated that it is important to look at the intensity and level of involvement the learner has with the activity. The level of participation by the learner may make a difference in how much the learner is affected by being involved, that is, the competencies developed by the learners.

\subsubsection{Social skill Competencies}

Malaysia education philosophy is to holistically develop individuals' potential to create a harmonious and balanced human intellectually, spiritually, emotionally and physically based on trust and obedience to God. Cabinet Committee Report outlined the objectives of education in Malaysia which is to produce a disciplined individual towards the family, community, educational institutions as well as the nation. Azmi and Hamsiah (2000) found out that the actual function of co-curricular activities is to enhance and strengthen interaction among learners. Cocurricular learning environment outside the classroom plays an important role in influencing a person's behavior. It is one of the important elements in the formation of learners' social skills. Children development is the environmental impact on the children as well as the children's characteristics towards the environment. Social skills facilitate acquisition of emotional intelligence which will define the excellence of learners in any situation. 
Intellectual intelligence alone is not enough for a person to be excellent. Co-curricular activities can help a person to build social skills in everyday life by interacting individually or collectively. It helps them to be brave in accepting the challenge as well as easily exposing their hidden talents. Learners need social competencies to help them interact and connect with the surroundings. Co-curricular activities are important because they serve as a key benchmark in fulfilling the national education policy which is unity among the learners of various races. Cocurricular activities are essential in establishing a harmonious society. Employers prefer workers who have the ability to interact, competent, have high moral integrity and can work as a team. Co-curricular activities are complementary to the needs and requirements of the curriculum which is providing opportunities for the learners to add measure and practice the skills, knowledge and values that are integrated in the classroom (Mohd Arif \& Amla, 2008).

\subsubsection{Leadership and Language skills}

According to Broh (2002), "Longitudinal studies on school sports have suggested that such participation raises learners' grades and test scores". Stephens and Schaben (2002) carried out a study investigating several sports that were played by the learners and discovered that learners who were involved in one sport at minimum at every year outperformed the ones who did not engage at any co-curricular activity and also failed in overall GPA, class rank, and GPA of mathematics (Stephens \& Schaben, 2002,). Similarly, the researchers discovered that learners who were involved in many sports possessed higher level of scholarship than the learners who had competed in only a few seasons or for only one year (Stephens \& Schaben, 2002,). In the case of using athletics in developing competencies among the learners in secondary schools, research shows that learners who participate in athletics are able to develop physically, mentally and emotionally while providing an experience that cannot be found in a classroom, Howard-Hmilton (2002). Participation in athletics enable learners to become self-disciplined and acquire good leadership skills. This statement was supported by a study which was done by Darling (2005), who said that learners become more creative and independent in their life because they have positive attitude towards participation in athletics.

Debate is a co-curricular and interscholastic event whereby learners are able to face off with one another on the structured centered exchange on issues of policy. This academic competition focuses on arguments based on evidence gathered by the learners themselves (Breger, 2000). Every debate comprises of two teams or having two learners taking opposing stands on the topic being discussed. Several studies propose that participation which is intensive at the level of high school improves critical thinking (Colbert, 2002). Involvement in discussion increases time together with debate peers and teachers via practices after - school and tournaments during weekends in the entire period of the year. Practically, the policy events on discussion entail training of six skills: interpreting and reading difficult text that is non-fiction, creating and writing the arguments utilizing or basing on the texts, verbal expression and evidence-based defense claims, hearing carefully and interpreting, arguments made by opponents, associating with the peers and management of time

(Warner and Bruschke, 2001; Collier, 2004). Maryadi (2008) cited in Khoironiyah, (2011) confirms how important participation in debate is to learners, that learners are motivated to think more so that they are able to defend what they stand for during the debate. Krieger (2005) also said that learners who participate in debate are able to acquire listening skills, speaking skills, and develop argumentative skills which will help them in writing persuasive speeches. The study was based on the following theories.

\subsubsection{Tinto's Interactionalist Theory}

The research relied on Interaction Theory of Tinto (2004), which agrees with the view that commitment level of learners at the start impacts on their subsequent competency and commitments. This theory was meant to be applied in education at the secondary level, and proposed that schools needed to find out ways that students can apply to ensure their interaction is increased, including involvement in the experiences outside classroom setting. such experiences are useful for students to acquire knowledge and skills as well as increase perseverance to learn and achieve more in their future life.

\subsubsection{Holistic approach theory}

This study was informed by the holistic approaches to curriculum development. Miller (2007) indicated that holistic approaches thrive on balance, inclusion and connection. According to the theory, all things have arisen mutually and are mutually supportive, in the sense they require one another as a condition for their existence. The curriculum content in Kenya has two major components namely the curriculum activities and co-curriculum activities. The teacher's participation in the co-curricular activities plays a major role in ensuring the success of the programs just like the way they participate in curriculum activities. Forbes (2003) noted that holistic education seeks to educate the whole child, (all parts of the child), educate the learner as a whole (not as assemblage of parts), and see the child as a part of a whole (society, humanity, environment, spiritual whole etc.) from which it is not meaningful to extract the learner. Thus, holistic education educators see this approach as reflecting a materialist and consumerist culture that has reduced schooling to the training of individuals to compete and consume in the global market place. Mahmoud, Jafari, Nasrabadi and Liaghatdra (2011) stressed that a curriculum that emphasizes one aspect at the expense of the other lacks balance and if skills, values and attitudes developed in learners do not 
feed into all aspects of the other, the connection and inclusion is lost. Teachers perception of the importance and value attached to co-curricular activities determines the quality of education that is offered in the schools. The forms of involvement that the teachers engage in with their learners as they participate in the co-curricular activities as well as the form and type of the activities determines the quality of education offered in the schools for learners' preparation into adult life in terms developing competencies. Miller (2007) further argues that a true education comes through the training of bodily organs and intelligent use of bodily organs ensures a faster way of developing the intellect.

\section{Research Methodology}

The researcher used a descriptive research design which was appropriate in describing teacher's perception of the use of debate and athletics in developing competencies among learners (Orodho (2005). The target population comprised of 80 teachers who were in charge of co-curricular activities. Census sampling technique was used hence all the 80 teachers formed the study sample. Questionnaires were used to collect data. They were appropriate as they facilitated data collection from diverse regions which is in line with the arguments of Kombo and Tromp (2006). According to Joppe (2000), validity evaluates whether research measures truly the required parameters or truthfulness of results. To ensure validity, the instruments which were used in the current study were thoroughly reviewed by an expert supervisor. The researcher conducted a pilot study of the questionnaires to test their reliability. It facilitated to determine suitability, clarity, and accuracy of instruments used. Data was analyzed and interpreted according to the research the objectives. It was presented using frequencies and percentages besides using information in tables for interpretation.

\section{Findings and Discussions}

5.1. Teachers' Perception of Participation in Athletics in Developing Competencies among Learners The study sought to find out teachers' perception of participation in athletics in developing competencies among learners. The findings were as summarized in Table 2. Table 2: Participation in Athletics in Developing Competencies among Learners

Competencies Developed

Teamwork

Time Management

Responsible

positive competition, that is, one may win or lose

which is the spirit of good governance and democracy later in life

Learners learn to abide by the rules associated with $5(25 \%)$ athletics hence they become law abiding citizens

SA
A

M

$\mathrm{D}$

SD

$$
8(40 \%) \quad 8(40 \%) \quad 1(5 \%) \quad 2(10 \%) \quad 1(5 \%)
$$

$3(15 \%)$

$13(65 \%)$

$1(5 \%)$

$2(10 \%)$

$1(5 \%)$

$3(15 \%) \quad 11(55 \%) \quad 3(15 \%) \quad 1(5 \%) \quad 2(10 \%)$

Key

SA- Strongly Agree

A-Agree

M- Moderate

D- Disagree

SD- Strongly Disagree

From the study findings, $80 \%$ of the respondents reported that participation in co-curricular activities helped secondary school learners to develop good communication skills. This implied that learners who participated in athletics interacted with each other so that they could form a group. For instance, learners formed different groups of training which helped them to work as a team even in their group discussions in academics. Extejt and Smith (2009), also found out that learners who participated in athletics were able to acquire an experience of being part 
of a team that works towards achieving common goals, therefore provided an opportunity for the learners to experience teamwork. This is in line with the findings of Rasmussen (2000) who found out that secondary school learners who participated in athletics were able to be good members of teams hence acquired teamwork skills.

The researcher found out that $65 \%$ of the respondents agreed that learners developed leadership skills through participation in athletics. From the findings it's clear that learners who participated in athletics were able to report on training in time and had good decision-making strategy which is in relation to time management. Darling (2005) supports the findings, that learners who participated in athletics became more independent which is an attribute of good leadership skills.

The results revealed that $55 \%$ of the respondents reported that learners who participated in athletics developed critical thinking and problem-solving skills. They were able to solve their issues well whenever they arose which helped them to become more responsible. Learners were able to adapt and act accordingly to any situation. Darling (2005), in his findings agreed with the findings, that learners who participated in athletics became more creative. According to the study findings, the researcher found out that $80 \%$ of the respondents reported that secondary school learners who participated in athletics developed good leadership skills. They were able to accept the outcome after competing with each other which is a sign of discipline. The learners also were aware that participation in athletics involved a win or a loss which was a sign of positive competition which is the spirit of good governance and democracy later in their life. This is in line with Guest and Schneider (2003) who found out that learners who participated in athletics were generally disciplined. Learners who participated in athletics were able to relate well with others during training and competitions. The study conducted by Broh (2002) is in line with the findings, that participation in athletics helped to promote learners' social skills in school and in their future life.

5.2 Teachers' Perception of Participation in Debate in Developing Competencies among Learners The researcher sought to find out the perception of the teachers on participation in debates in developing competencies among learners in public secondary schools. The findings were as summarized in Table 5.

Table 4: Participation in Debates in Developing Competencies among learners

\begin{tabular}{|c|c|c|c|c|c|}
\hline Competencies Developed & SA & $\mathrm{A}$ & $\mathrm{M}$ & $\mathrm{D}$ & SD \\
\hline Critical Thinking & $7(35 \%)$ & $8(40 \%)$ & $1(5 \%)$ & $3(35 \%)$ & $1(5 \%)$ \\
\hline Written and Oral Communication Skills & $3(15 \%)$ & $13(65 \%)$ & $1(5 \%)$ & $2(10 \%)$ & $1(5 \%)$ \\
\hline $\begin{array}{l}\text { Learners Who Participate in Debates Builds Their } \\
\text { Self-Esteem }\end{array}$ & $7(35 \%)$ & $8(40 \%)$ & $2(10 \%)$ & $2(10 \%)$ & $1(5 \%)$ \\
\hline Improved Personal Confidence & $13(65 \%)$ & $4(20 \%)$ & $1(5 \%)$ & $1(5 \%)$ & $1(5 \%)$ \\
\hline Reading Skills & $7(35 \%)$ & $8(40 \%)$ & $1(5 \%)$ & $2(10 \%)$ & $1(5 \%)$ \\
\hline \multirow[b]{2}{*}{ Good Decision Making } & $9(45 \%)$ & $8(40 \%)$ & $1(5 \%)$ & $1(5 \%)$ & $1(5 \%)$ \\
\hline & $12(60 \%)$ & $5(25 \%)$ & $1(5 \%)$ & $1(5 \%)$ & $1(5 \%)$ \\
\hline Presentation and Research Skills & & & & & \\
\hline
\end{tabular}

Key

SA-Strongly agree

A-agree

M-Moderate

D-Disagree

SD-Strongly disagree

Findings revealed that $75 \%$ of the respondents reported that learners who participated in debate developed their thinking skills well, while $40 \%$ of the respondents revealed that learners did not develop critical thinking due to participation in debate. The researcher found out that learners who participated in debate were able to build links between words and ideas which made concepts more meaningful during debate discussion. This study findings was in line with the study conducted by Khoironiyah (2011) who found out that learners who participated in debate were much motivated to think more so that they would be able to put a well defense during participation on what they stood for during the period of debate. Krieger (2005) also agreed with the researcher that participation in debate indeed led to development of good thinking skills. In his study, he found out that participation in debate led to development of argumentation skills, which helped the learners to have good writing and persuasive speeches during the debate period. The study findings revealed that $80 \%$ of the respondents revealed that 
participation in debate led to development of fluent communication skills. The researcher was able to find out that learners who participated in debate interacted well with others so that they can defend their sides well. It also implied that learners persuaded well those learners who were on the opposing side with facts so as to agree with what they stood for. In line with this, the research carried out by Krieger (2005) agreed with the researcher that learners who participated in debate were able to acquire good skills of listening and speaking and writing practice, and effectively developed argumentation skills which helped them during writing and persuasion speeches in debate period.

According to the research findings, the researcher found out that $75 \%$ of the respondents reported that learners who participated in debate developed good social skills. This implied that learners who participated in debate were given enough time to give out their views during presentation without any interruption and also related well with the resource persons when they were gathering information to solidify their evidence. Learners also listened to one another's point of view without much disturbance so that they can be able to finish their presentation well. Breger (2000) agreed with the research findings that indeed participation in debate contributed to development in social skills. Berger's research findings concluded that debate involved two teams which included two learners who took opposing stands and focused on arguments which were based on evidence which the learners gathered themselves. Also, Colbert (2002) confirmed through his research findings that participation in debate increased time learners spent together with their debate peers and teachers.

The researcher found out that $85 \%$ of the respondents reported that learners who participated in debate developed good leadership skills. The researcher learnt through the research findings that learners who participated in debate were responsible enough because they were able to carry out a lot of research on their own on the topic which they were to discuss so that they gather more information which formed part of the evidence in order to assist them to confidently defend the issue under discussion without any fear. The research findings were supported by the research done by Breger (2000) who through his findings said that debate was an academic competition which focused on the arguments which were based on evidence which the learners gathered themselves in order to develop confidence during debate. Learners who participated in debate developed good communication skills. This was confirmed by the research findings where by $75 \%$ of the respondents reported that learners developed good communication skills. It implied that learners who participated in debate were able to gather enough information which formed part of evidence to assist them to argue on issues under discussion during debate period. The learners got most of the information from reading the books and newspapers and any other materials which led to development of reading skills. This is in line with Breger (2000) who found out that learners who participated in debate, improved their reading skills since the learners themselves were able to gather the necessary information required during the period of debate.

From table 4 above, the researcher found out that $85 \%$ of the respondents agreed that indeed participation in debate helped learners develop leadership skills as compared to $10 \%$ of the respondents who reported that participation in debate did not assist learners develop good leadership skills. This implied that learners who participated in debate recognized how other learners thought on the issue on the issue at hand so as to improve the ability to cooperate and resolve conflicts. The study done by Breger (2000) also agreed with the researcher that debate comprised two opposing teams which had two learners taking different stands, that is, thinking differently on the topic which is being discussed.

The researcher revealed from the research findings that $85 \%$ of the respondents reported that participation in debate helped learners develop good critical thinking skills. This implied that learners who participated in debate were allowed to choose pros and cons with one topic independently. Also learners had an ability to analyze, criticize and advocate ideas from their own reasoning so as to reach on a factual judgmental conclusion which is backed with evidence. This is in line with United States of America DOE Assessment Governing Board (2008), which agreed with the researcher that learners who participated in debate were in a good position to identify information which came from different texts to understand the subject. Again Khoironiyah (2011), in his research he found out that participation in debate was something important to learners since the learners were motivated to think broadly so that they are able to put solid defense on what they stood for during the period of defense.

\section{Conclusion}

Athletics and debates are enablers for developing competencies among learners by enriching their physical, psychological, emotional and cognitive growth. They support Learners to strengthen their inter- personal relationships with peers and teachers, upgrade their academic progress and improve their organization skills. School managers should guide students to participate in the co-curricular activities in a conducive environment. Specifically, learners acquire skills such as: teamwork, social skills, communication skills, critical thinking, positive competition, research skills, decision making and time management. Teachers should reflect on decisions concerning involvement of learners in the activities to ensure a balance among the three domains of learning: the cognitive, psychomotor and the affective. The co-curricular activities can be used to empower learners in their hidden talents and facilitate them to play effective roles in the development of the society. 


\section{REFERENCES}

Bauer, K.W. and Liang, Q. (2003). The effect of personality and pre-university characteristics on first year activities and academic performance. Journal of college student development.

Bashir, Z. (2012). The effectiveness of co-curricular activities on academic achievements of secondary schools' students in District Abbottabad Pakistan.

Botvin, G., J. \& Griffin, K., W. (2004). Life skills training: Empirical findings and future directions. Journal of primary prevention.

Breger, B. (2000). Overview of the urban debate program. Rostrum, 75:14. Bringing up Girls in Science, (2003). Bugs - Parents (University of North Texas). Retrieved February 26, 2005, from http:/ www.Coe.edu/ bugs/parents.Index.Html.

Castelli, D M. Hillman CH, Buck SM, Erwin HE (2007). Physical Fitness and academic achievement in third and fifth - grade students. Journal of sport and exercise psychology.

Coakley, J., J. (2001). Sport in the society: Issues \& Controversies. Health professions series. McGraw-Hill 2001.

Colber, K. (2002). Enhancing critical thinking ability through academic debate.

Perspectives in controversy: selected essays from Contemporary Argumentation and Debates Education Association. Pp, 71-100.

Danish, S. J., Forneris, T., Hodge, K., \& Heke, I. (2004). Enhancing youth development through sport. World Leisure 3, 38-39

Darling, N. Caldwell L. L, Smith R. (2005). Participation in school-based extracurricular activities and adolescent adjustment. Journal of Leisure Research.

Extejt, M., \& Smith, J. (2009). Leadership development through sports, teams participation. Journal of Leadership Education.

Forbes, S. (2003). Holistic Education: An Analysis of its Ideas and Nature. Brandon, VT: Foundation for Educational Renewal.

Gardner, M., Roth, J., \& Brooks-Gunn, J. (2008). Adolescents' activities and development success 2 and 3 years after high school: Development Psychology.

Geust, A. and Schneider, B. (2003). Adolescents' extracurricular participation in context: the mediating effects of schools' communities, and identity. Sociology of Education.

Joppe, M. (2000). The Research Process. Retrieved February 251998.

Kombo, K. D. and Tromp, L. A.D. (2006). Proposal and thesis writing: an introduction. Nairobi: Pauline Publications Africa.

Koutsoupidou, T., and Hargreaves, D. (2009); An experimental study of the effects improvisation on the development of children's creative thinking in music. Psychology of music 37(3)

Khoironiyah. (2011). the implementation of debate in teaching speaking at eleventh year students of SMA Negeri 2 Rembang in the academic year 2011/2012. English 2008C FKIP Unirow Tuban.

Krieger, D. (2005). Teaching Debate to ESL Students: A Six Class Unit. The Internet TESL Journal. Vol. XI, No. 2, February, 2005.

Kumar, A. (2004). Status of co-curricular activities and extra-curricular activities in primary schools of Nepal: Problems and prospects. Research Centre for Educational Innovation and Development Tribhuran University Balkhu, Kathmandu Nepal.

Lange, G, D., and Technicon, (2000). The identification of the most important technical skills required by entry level engineering students when they assume employment. Journal of cooperative education.

Mahoney, J.L. (2000). School extracurricular activity participation as a moderator in the development of antisocial patterns. Child Development, 71 (2):502-516.

2003 Mahoney, J. L.,Cairos, B. D. and Farwer, T.W. (). Promoting interpersonal competence and educational success through extra-curricular activity participation. Journal of educational psychology.

Mahoney, J.L. and Eccless J.S.(2006). Organized activity participation, positive youth development and the overscheduling hypothesis. SRCD social policy report.

Marsh, H. W. and Kleitman, S (2002).Extracurricular activities. The good, the bad and the nonlinear. Harvard Educational Review, 72, 464-512.

Miller, J. P. (2007). The Holistic Curriculum. Toronto: University of Toronto Press.

Mohd H., A., H. (2002). The role of co-curricular activities in developing individual leadership skills.

Morrissey, K. (2005). The relationship between out-of-school activities and positive youth development: an investigation of the influence of communities and family.

Ongong'a, J. O., Okwara, M. O. and Okello, T.M. (2010). Sports and secondary school education in Kenya. Journal of Education Research.

Orodho, J.A. (2005). Elements of Education and Social Science Research Methods. Masola Publishers Nairobi.

Quek, A., H. (2005). "Learning for the workplace: a case study in graduate employees' generic competencies", Journal of workplace learning. 
Rohanida Abdul and Mohd Sofian Omar Fauzee (2002). Developing human value through extra- Curricular activities. The journal of Human Resource and Adult Learning3(1).

Simon, R. (2004). Fair play: The ethics of sport ( $2^{\text {nd }}$ ed.). Boulder, Co: Westview press.

Stephens,L.J. and Schaben, L . A (2002). The effect of interscholastic sports participation on academic achievement of middle level school activities. National Association of Secondary School Principals Bulletin. 86, 34-42.

Tinto, V.S. (2004). Student retention and graduation: facing the truth, living with the consequences. Washington DC: The Pell Institute for the Study of Opportunity in Higher Education.

Winston,B., Bonney, W., Miller, T., and Dagley, J. (2008). Promoting student development through intentionally structured groups. San Fransisco:Jossey-Bass.

Acknowledgement

Our Gratitude goes to National Commission for Science, Technology and Innovation for authorizing the research to be conducted. We thank all respondents who enabled us complete the study successfully and provided data for analysis. 